\title{
HUBUNGAN ANTARA POLA KONSUMSI PANGAN DAN AKTIVITAS FISIK DENGAN KEJADIAN OSTEOPOROSIS PADA LANSIA DI PANTI WERDHA BOGOR
}

\author{
(Relationship between Food Consumption and Physical Activity with Risk of Osteoporosis \\ in Elderly at Nursing Home in Bogor)
}

Avliya Quratul Marjan+1* dan Sri Anna Marliyati ${ }^{1}$

1'Departemen Gizi Masyarakat, Fakultas Ekologi Manusia (FEMA), Institut Pertanian Bogor, Bogor 16680

\begin{abstract}
The objective of this study was to analyze relationship between food consumption and physical activity with incidence of osteoporosis in elderly at nursing home in Bogor. The design of this study was cross sectional. Subjects were taken purposively with certain criteria and the number of subjects obtained were 37 elderly. Results showed that the adequacy level of energy and protein were normal, phosphor was in adequate category and calcium was in deficient category. There was no significant relationship between nutritional status, the adequacy level of energy, protein and phosphor with risk of osteoporosis ( $p>0.05)$. However, there was a significant relationship between the adequacy level of calcium and physical activity level with risk of osteoporosis $(p<0.05)$. The deficit adequacy level of calcium and physical activity was a risk factor for the risk of osteoporosis.
\end{abstract}

Keywords: elderly, food consumption, osteoporosis, physical activity

\begin{abstract}
ABSTRAK
Tujuan penelitian ini adalah untuk mengetahui hubungan antara pola konsumsi pangan dan aktivitas fisik dengan kejadian osteoporosis pada lansia di Panti Werdha Bogor. Penelitian ini menggunakan desain cross sectional. Subjek diambil secara purposive dengan kriteria tertentu dan jumlah subjek yang digunakan dalam penelitian ini adalah 37 orang lansia. Hasil penelitian menunjukkan bahwa tingkat kecukupan energi dan protein adalah normal, fosfor pada kategori cukup dan kalsium diklasifikasikan pada kategori kurang. Tidak terdapat hubungan yang signifikan antara status gizi, tingkat kecukupan energi, protein, dan fosfor dengan kejadian osteoporosis $(p>0.05)$. Namun, terdapat hubungan yang signifikan antara tingkat kecukupan kalsium dan aktivitas fisik dengan kejadian osteoporosis $(p<0.05)$. Tingkat kecukupan kalsium dan tingkat aktivitas fisik yang kurang merupakan faktor risiko terhadap kejadian osteoporosis.
\end{abstract}

Kata kunci: aktivitas fisik, lansia, osteoporosis, pola konsumsi pangan

"Korespondensi: Departemen Gizi Masyarakat, Fakultas Ekologi Manusia (FEMA), Institut Pertanian Bogor, Bogor 16680. Email: avliya.q.ajangiziipb@gmail.com 


\section{PENDAHULUAN}

Pada umumnya usia lanjut diartikan sebagai usia saat memasuki masa pensiun yang di Indonesia dapat berkisar antara usia di atas 55 tahun. Proporsi penduduk lanjut usia (lansia) Indonesia meningkat dari $1.1 \%$ menjadi $6.3 \%$ dari total populasi. Peningkatan jumlah lansia memengaruhi aspek kehidupan mereka seperti terjadinya perubahan fisik, biologis, psikologis, dan sosial sebagai akibat proses penuaan. Salah satu perubahan fisik yang terjadi seiring pertambahan usia adalah terjadinya penurunan massa tulang yang sering disebut osteoporosis.

Osteoporosis adalah suatu penyakit yang ditandai dengan berkurangnya massa tulang dan adanya perubahan mikroarsitektur jaringan tulang yang berakibat menurunnya kekuatan tulang dan meningkatnya kerapuhan tulang serta risiko terjadinya patah tulang (Harvey \& Cooper 2004). Terdapat banyak faktor yang menyebabkan terjadinya osteoporosis diantaranya konsumsi pangan dan aktivitas fisik (Lane 2003). Studi epidemiologis yang dilakukan menunjukkan bahwa asupan zat gizi makro dan mikro dalam tubuh merupakan salah satu faktor yang dapat memperlambat kejadian osteoporosis di masa lanjut usia. Selain memenuhi asupan zat gizi, perlu juga memperhatikan aktivitas fisik. Menurut Hoger dan Hoeger (2005), kurangnya aktivitas fisik pada seorang individu di masa muda akan berdampak pada penurunan kepadatan tulang di masa lanjut usia.

Tujuan penelitian ini adalah mengkaji pola konsumsi pangan, status gizi, tingkat kecukupan energi, protein, kalsium, dan fosfor; mengkaji aktivitas fisik; mengkaji nilai densitas tulang; dan menganalisis hubungan antara pola konsumsi pangan dan aktivitas fisik dengan kejadian osteoporosis pada lansia di Panti Werdha Bogor.

\section{METODE}

\section{Desain, Tempat, dan Waktu}

Penelitian ini menggunakan desain cross sectional yang dilaksanakan di Panti Werdha Tresna dan Panti Werdha Hanna Bogor pada bulan Maret-April 2013. Pemilihan tempat dilakukan secara purposive.

\section{Jumlah dan Cara Penarikan Subjek}

Cara penarikan subjek penelitian ini berdasarkan perhitungan minimal ukuran sampel dalam bidang kesehatan. Pengambilan subjek penelitian ini dilakukan dengan mencari subjek yang memenuhi kriteria inklusi dan eksklusi serta dengan mempertimbangkan jika ada subjek yang drop out selama penelitian berlangsung. Subjek yang digunakan dalam penelitian ini adalah 37 orang lansia dengan kriteria subjek sehat, dapat berkomunikasi dengan baik, tidak memiliki masalah dalam daya ingat, masih dapat beraktivitas dengan baik, dan bersedia untuk menjadi subjek penelitian.

\section{Jenis dan Cara Pengumpulan Data}

Jenis data yang dikumpulkan meliputi data primer dan sekunder. Data primer ini meliputi karakteristik subjek, kebiasaan makan, status gizi, konsumsi pangan, aktivitas fisik dan nilai densitas tulang. Data sekunder meliputi data gambaran umum dan jadwal kegiatan panti yang dijadikan sebagai lokasi penelitian.

Penelitian ini menggunakan metode semi kuantitatif untuk mengetahui frekuensi makan dan kebiasaan makan subjek dengan wawancara menggunakan Food Frequency Questionnaire (FFQ). Metode kuantitatif recall $2 \times 24$ jam digunakan untuk mengetahui konsumsi pangan subjek.

Pengumpulan data dilakukan dengan wawancara menggunakan kuesioner. Data status gizi diperoleh dengan mengukur berat badan dengan timbangan injak dan tinggi badan dengan microtoise. Nilai densitas tulang diukur dengan bone densitometer.

\section{Pengolahan dan Analisis Data}

Analisis yang digunakan dalam penelitian ini adalah analisis deskriptif dan analisis inferensia. Analisis deskriptif digunakan untuk menggambarkan karakteristik subjek, kebiasaan makan, frekuensi konsumsi makan subjek, tingkat kecukupan gizi, aktivitas fisik subjek, status gizi, dan densitas tulang untuk melihat risiko kejadian osteoporosis pada subjek. Analisis inferensia digunakan untuk melihat hubungan antar variabel. Hubungan antara karakteristik subjek, tingkat kecukupan energi, protein, kalsium, fosfor. Status gizi dan aktivitas fisik dengan kejadian osteoporosis dianalisis dengan uji epidemiologi menghitung nilai Odds Ratio (OR) menggunakan uji regresi binary logistic. Uji signifikansi dilakukan dengan mencari nilai $p$-value $(p<0.05)$ dan Confidence Interval/Cl 95\%. Faktor-faktor yang berpengaruh terhadap kejadian osteoporosis pada lansia di Panti Werdha Bogor dianalisis dengan menggunakan uji multiregresi logistik.

\section{HASIL DAN PEMBAHASAN}

\section{Karakteristik Subjek}

Subjek dalam penelitian ini adalah 37 orang wanita lanjut usia yang berusia di atas 55 tahun. Rentang usia subjek berkisar antara 57-88 tahun. Sebesar $75.7 \%$ subjek berada pada rentang usia lebih atau sama dengan 65 tahun, dan sebesar $24.3 \%$ berada pada rentang usia 55-64 tahun.

\section{Nilai Densitas Tulang}

Menurut Broto (2004), pemeriksaan kepadatan tulang dengan bone densitometer merupakan 
pemeriksaan akurat dan presisi untuk menilai kepadatan tulang, sehingga dapat digunakan untuk menilai prediksi fraktur dan diagnosis osteoporosis. Berdasarkan Anlene Bone Health Check yang sesuai dengan Harvey dan Cooper (2004), diketahui bahwa bagi individu yang berusia lanjut, nilai normal densitas tulang ( $t$-score) adalah $-1 \leq \mathrm{SD}<2.5$. Subjek dengan nilai densitas tulang $\leq-2.5$ tergolong dalam kategori osteoporosis atau telah berisiko mengalami osteoporosis. Berdasarkan kategori nilai $t$ score Anlene Bone Health Check, sebagian besar subjek (78.4\%) mengalami osteoporosis dan sebesar $21.6 \%$ subjek tidak osteoporosis ( $t$-score>-2.5). Sebaran subjek berdasarkan kategori nilai densitas tulang disajikan pada Tabel 1.

Tabel 1. Sebaran Subjek berdasarkan Kategori Nilai Densitas Tulang ( $t$ score)

\begin{tabular}{lcc}
\hline \multicolumn{1}{c}{ Kategori } & $\mathrm{n}$ & $\%$ \\
\hline WHO 1994: & & \\
$\quad$ Normal $(-1 \leq \mathrm{SD}<2.5)$ & 2 & 5.4 \\
$\quad$ Osteopenia Risk $(-2.5 \leq \mathrm{SD}<-1)$ & 6 & 16.2 \\
$\quad$ Osteoporosis $(<-2.5)$ & 29 & 78.4 \\
Anlene Bone Health Check: & & \\
$\quad$ Normal $(>-2.5)$ & 8 & 21.6 \\
$\quad$ Osteoporosis $(\leq-2.5)$ & 29 & 78.4 \\
\hline
\end{tabular}

\section{Pola Kosumsi Pangan}

Frekuensi makan. Hasil penelitian menunjukkan bahwa subjek yang osteoporosis mengonsumsi nasi sebesar $20.5 \mathrm{kali} / \mathrm{minggu}$, dan subjek yang tidak osteoporosis rata-rata mengonsumsi nasi sebesar $21 \mathrm{kali} /$ minggu sehingga rata-rata dari keseluruhan subjek mengonsumsi nasi 2-3 kali/hari. Frekuensi konsumsi pangan hewani yang paling sering di konsumsi dari seluruh subjek adalah telur, yaitu 5-6 kali/minggu. Selain telur, jenis pangan hewani yang sering dikonsumsi oleh subjek adalah susu yaitu rata-rata $3.1 \mathrm{kali} /$ minggu. Tahu dan tempe adalah pangan sumber protein nabati yang paling sering dikonsumsi oleh seluruh subjek. Ratarata frekuensi konsumsi tahu dan tempe pada subjek yang osteoporosis dan tidak osteoporosis adalah sebanyak $8.8 \pm 4.1$ dan $8.8 \pm 4.1 \mathrm{kali} /$ minggu.

Wortel dan jeruk merupakan jenis sayuran dan buah yang paling sering dikonsumsi subjek. Frekuensi konsumsi wortel pada subjek yang mengalami osteoporosis rata-rata $3.8 \mathrm{kali} /$ minggu dan subjek yang tidak osteoporosis mengonsumsi wortel $2.8 \mathrm{kali} /$ minggu. Frekuensi konsumsi jeruk subjek yang osteoporosis rata-rata sebanyak $2.3 \mathrm{kali} /$ minggu, sedangkan subjek yang tidak osteoporosis sebanyak $2.8 \mathrm{kali} /$ minggu. Rata-rata frekuensi konsumsi pangan sumber kalsium yang paling sering dikonsumsi subjek yaitu kacang-kacangan dan olahannya (5.2 kali/minggu). Hal ini disebabkan keseluruhan subjek hampir setiap hari mengonsumsi tahu dan tempe yang merupakan olahan dari kacang-kacangan. Menurut Setyorini et al. (2009), frekuensi konsumsi pangan sumber kalsium oleh seseorang akan memengaruhi jumlah kalsium yang masuk ke dalam tubuh.

Kebiasaan makan. Sebagian besar subjek memiliki kebiasaan makan yang sudah cukup baik dengan persentase sebesar $89.2 \%$ subjek selalu sarapan pagi dan hanya sebesar $10.8 \%$ subjek yang tidak sarapan pagi. Hal ini karena ada gangguan kesehatan pada subjek sehingga subjek merasakan mual jika sudah makan di pagi hari. Makanan yang biasa dikonsumsi keseluruhan subjek pada saat sarapan adalah nasi dan lauk pauk $(97.3 \%)$ yang menunjukkan bahwa sarapan pagi subjek terdiri dari makanan sumber zat tenaga, sumber zat pembangun dan sumber zat pengatur. Waktu sarapan subjek berkisar pada rentang pukul 05.00-09.00 WIB, dimana sebagian besar subjek (81.1\%) sudah sarapan pada pukul 05.00-06.30. Berdasarkan wawancara yang dilakukan juga menunjukkan bahwa seluruh subjek terbiasa untuk makan siang dan makan malam secara teratur.

Menurut kesukaan terhadap makanan, sebagian besar subjek yang tidak osteoporosis menyukai lauk hewani (37.5\%). Hal ini menunjukkan bahwa pada subjek yang tidak osteoporosis kemungkinan besar banyak mendapatkan asupan mineral kalsium dan fosfor dari lauk hewani yang dikonsumsi. Pada subjek yang mengalami osteoporosis memiliki persentase kesukaan terbesar pada makanan dari luar panti (jajanan) yaitu sebesar $34.5 \%$.

Kebiasaan minum. Penelitian ini menunjukkan sebagian besar subjek yang tidak osteoporosis (75.0\%) mengonsumsi air putih sebanyak $6-8$ gelas dalam sehari. Hal ini berbeda dengan subjek yang mengalami osteoporosis, sebagian besarnya (75.9\%) mengonsumsi air putih $<6$ gelas sehari.

Hasil wawancara yang telah dilakukan menunjukkan bahwa dari seluruh subjek sebesar $27.0 \%$ sering mengonsumsi susu. Sebesar $75.0 \%$ subjek yang tidak osteoporosis sudah terbiasa minum susu sejak balita hingga sekarang. Hal ini merupakan salah satu faktor yang mengakibatkan kepadatan tulang subjek lansia masih baik (normal) dan tidak mengalami osteoporosis hingga saat ini. Subjek yang mengalami osteoporosis rata-rata memiliki kebiasaan minum susu dalam waktu baru-baru ini (34.9\%) sehingga berdampak pada risiko kejadian osteoporosis. Individu yang memiliki kebiasaan minum susu sejak kecil memiliki kesehatan tulang yang lebih baik di masa lanjut usia (McCabe et al. 2004).

\section{Status Gizi}

Status gizi didefinisikan sebagai keadaan kesehatan tubuh seseorang atau kelompok orang yang diakibatkan oleh konsumsi, penyerapan (absorpsi), dan penggunaan (utilisasi) zat-zat gizi makanan (Hsu 
et al. 2006). Hasil penelitian menunjukkan bahwa sebagian besar subjek (40.5\%) memiliki status gizi lebih (IMT>22.9). Sebagian besar subjek yang tidak mengalami osteoporosis memiliki status gizi lebih sebesar $50.0 \%$, sedangkan yang berstatus gizi normal dan kurus masing-masing sebesar $25 \%$. Subjek yang osteoporosis sebagian besar memiliki status gizi normal (41.4\%), sebesar $37.9 \%$ memiliki status gizi lebih dan $20.7 \%$ memiliki status gizi kurang. Subjek yang berada pada kategori gizi lebih cenderung disebabkan karena mengonsumsi pangan dalam jumlah banyak dan tidak melakukan aktivitas fisik. Sebaliknya, subjek yang berada pada kategori gizi kurang cenderung mengonsumsi pangan dalam jumlah sedikit dan juga karena terdapat gangguan kesehatan yang menyebabkan penurunan nafsu makan. Menurut Hsu et al. (2006), untuk mencapai status gizi yang baik diperlukan pangan yang mengandung cukup zat gizi dan aman.

\section{Tingkat Kecukupan Gizi}

Hitz (2007) menyebutkan bahwa zat gizi merupakan faktor penentu dari kesehatan tulang. Tingkat kecukupan zat gizi merupakan faktor penting yang dalam perkembangan, perawatan massa tulang dan pencegahan osteoporosis. Pada penelitian ini tingkat kecukupan gizi yang dilihat adalah tingkat kecukupan energi, protein, kalsium dan fosfor.

Rata-rata konsumsi energi dan protein dari keseluruhan subjek adalah $1648 \mathrm{kkal}$ dan $51 \mathrm{~g}$. Rata-rata tingkat kecukupan energi $(100.7 \%)$ dan protein (102.3\%) total subjek berada pada kategori normal. Berdasarkan kategori osteoporosis, subjek yang tidak osteoporosis memiliki rata-rata tingkat kecukupan energi dan protein sebesar $97.3 \%$ dan 95.9\%, sedangkan tingkat kecukupan energi dan protein subjek yang osteoporosis adalah $101.6 \%$ dan $104.0 \%$.

Tingkat kecukupan energi subjek secara keseluruhan berada pada kategori normal yaitu sebesar 62.2\%. Pada tingkat kecukupan protein keseluruhan subjek sebagian besar dalam kategori defisit (43.2\%). Pada penelitian ini diperoleh data konsumsi protein nabati lebih tinggi dibandingkan dengan protein hewani. Rendahnya konsumsi protein hewani diduga karena dari keseluruhan subjek banyak yang tidak menyukai makanan sumber protein hewani dengan alasan kesehatan tertentu.

Rata-rata konsumsi kalsium dan fosfor dari keseluruhan subjek adalah $595 \mathrm{mg}$ dan $838 \mathrm{mg}$. Tingkat kecukupan kalsium rata-rata keseluruhan subjek masih berada dalam kategori kurang yaitu $74.4 \%$, sedangkan tingkat kecukupan fosfor ratarata keseluruhan subjek adalah $139.7 \%$ yang sudah berada dalam kategori cukup. Berdasarkan kategori osteoporosis, subjek yang tidak osteoporosis memiliki rata-rata tingkat kecukupan kalsium dan fosfor sebesar $72.2 \%$ dan $139.7 \%$, sedangkan tingkat kecu- kupan kalsium dan fosfor subjek yang osteoporosis adalah $75.0 \%$ dan $139.7 \%$.

Kecukupan asupan kalsium sangat penting untuk mencapai massa tulang puncak optimal dan mengurangi laju kehilangan tulang karena bertambahnya usia. Tingkat kecukupan kalsium pada subjek yang mengalami osteoporosis sebagian besar berada pada kategori defisit (75.9\%), sedangkan pada subjek yang tidak osteoporosis sebagian besar berada pada kategori normal (75.0\%).

Pada tingkat kecukupan fosfor sebagian besar subjek yang mengalami osteoporosis dan subjek yang tidak osteoporosis berada dalam kategori normal yaitu masing-masing $93.1 \%$ dan $75.0 \%$. Beasley et al. (2010) menyatakan bahwa fosfor banyak terdapat di dalam makanan, sehingga jarang bagi seorang individu mengalami kekurangan fosfor dan rata-rata tingkat kecukupan fosfor tergolong cukup pada individu yang normal dan tidak mengalami penyakit tertentu.

\section{Aktivitas Fisik}

Aktivitas fisik pada subjek dalam penelitian ini dikelompokkan menjadi 18 jenis aktivitas dengan rata-rata alokasi waktu yang dilakukan pada 3 hari yaitu pada hari dengan kegiatan senam rutin, hari dengan kegiatan keterampilan dan hari libur. Kegiatan yang paling lama dilakukan subjek adalah tidur yang terbagi atas tidur siang dan tidur malam. Rata-rata kegiatan tidur malam paling besar pada hari libur yaitu $6.6 \pm 0.9$ jam, sedangkan tidur siang memiliki rata-rata yang hampir sama setiap hari. Selain tidur, kegiatan harian yang paling sering dilakukan subjek adalah duduk-duduk dengan alokasi waktu paling besar pada hari mengerjakan keterampilan, yaitu $3.3 \pm 1.4$ jam. Kegiatan olahraga adalah kegiatan yang paling jarang dilakukan subjek pada hari-hari libur maupun pada hari mengerjakan keterampilan yaitu dengan alokasi waktu masingmasing sebesar $0.02 \pm 0.1$ jam dan $0.03 \pm 0.1$ jam.

Secara keseluruhan tingkat aktivitas fisik subjek termasuk dalam kategori aktivitas ringan (81.1\%), namun terdapat perbedaan sebaran antara subjek yang tidak osteoporosis dengan yang osteoporosis, dimana sebesar $89.7 \%$ yang osteoporosis memiliki tingkat aktivitas ringan, sedangkan pada subjek yang tidak osteoporosis hanya sebesar $50.0 \%$ yang memiliki tingkat aktivitas ringan.

\section{Hubungan Karakteristik Subjek dengan Kejadian Osteoporosis}

Berdasarkan analisis antara subjek yang berusia 55-64 tahun dengan subjek yang berusia $\geq 65$ tahun diketahui bahwa pada selang $\mathrm{Cl}: 0.08-2.35$ terdapat angka 1, maka usia 55-64 tahun belum merupakan faktor penghambat terjadinya osteoporosis pada subjek penelitian ini. Hal ini menjelaskan bahwa meningkatnya usia bukanlah satu-satunya 
faktor yang berpengaruh terhadap kejadian osteoporosis.

Berdasarkan analisis antara tingkat pendidikan rendah dengan tingkat pendidikan tinggi pada subjek diketahui bahwa pada selang $\mathrm{Cl}$ : $0.28-3.84$ terdapat angka 1 , maka tingkat pendidikan rendah belum merupakan faktor risiko terjadinya osteoporosis pada subjek penelitian ini. Meskipun tingkat pendidikan subjek masih rendah, namun beberapa subjek dalam penelitian ini sudah mencukupi kebutuhan gizinya dan terbiasa melakukan aktivitas fisik atau olahraga sejak muda yang menurut Sizer dan Whitney (2006) merupakan salah satu faktor yang memengaruhi kepadatan tulang di masa lanjut usia.

Penelitian yang dilakukan oleh Gur et al. (2003) menyatakan bahwa wanita yang memiliki anak $\geq 3$ orang berisiko untuk mengalami osteoporosis dan fraktur lebih rendah dibandingkan dengan wanita yang tidak pernah punya anak. Berdasarkan analisis antara subjek yang tidak menikah dengan subjek yang menikah diketahui pada selang nilai $\mathrm{Cl}$ : 0.23-21.7 terdapat angka 1, maka status pernikahan belum merupakan faktor risiko terjadinya osteoporosis pada subjek penelitian ini.

Berdasarkan analisis besar keluarga pada subjek penelitian ini diketahui bahwa pada selang $\mathrm{Cl}$ : 0.21-3.93 terdapat angka 1, maka besar keluarga belum merupakan faktor penghambat terjadinya osteoporosis pada subjek penelitian ini. Hal ini memperkuat pernyataan Lane (2003), dimana status pernikahan dan besar keluarga bukan merupakan salah satu faktor risiko penyebab osteoporosis.

\section{Hubungan Tingkat Kecukupan Energi, Protein, Kal-} sium, dan Fosfor dengan Kejadian Osteoporosis

Berdasarkan analisis antara tingkat kecukupan energi lebih dengan tingkat kecukupan energi normal menunjukkan bahwa tingkat kecukupan energi yang lebih berpeluang menurunkan kejadian osteoporosis dibandingkan dengan tingkat kecukupan energi yang normal. Hal ini sesuai dengan Hsu et al. (2006) yang menyatakan peningkatan jumlah energi akan berdampak pada status gizi yang lebih dan memiliki efek positif terhadap kepadatan mineral tulang. Namun, tingkat kecukupan energi yang lebih maupun tingkat kecukupan energi kurang belum merupakan faktor penghambat terjadinya osteoporosis pada subjek penelitian ini.

Berdasarkan hasil analisis antara subjek yang memiliki tingkat kecukupan protein kurang dengan tingkat kecukupan protein normal menunjukkan bahwa tingkat kecukupan protein kurang dapat berpeluang menjadi faktor risiko terhadap kejadian osteoporosis dibandingkan dengan tingkat kecukupan protein yang normal. Hasil ini menguatkan beberapa penelitian yang telah dilakukan yang mengindikasikan bahwa asupan protein yang kurang berhubungan dengan kepadatan mineral tulang yang kurang dan risiko osteoporosis yang tinggi (Rapuri et al. 2003).

Berdasarkan hasil analisis antara subjek yang memiliki tingkat kecukupan protein lebih dengan tingkat kecukupan protein normal menunjukkan bahwa tingkat kecukupan protein lebih dapat berpeluang menjadi faktor risiko terhadap kejadian osteoporosis dibandingkan dengan tingkat kecukupan protein yang normal. Hal ini sesuai dengan penelitian Dawson-Hughes (1996) yang menyebutkan bahwa terjadinya osteoporosis juga disebabkan oleh asupan protein berlebih yang dapat meningkatkan pengeluaran kalsium lewat urin.

Subjek yang memiliki tingkat kecukupan kalsium dalam kategori kurang berpeluang mengalami osteoporosis 9 kali lebih tinggi dibandingkan dengan subjek yang memiliki tingkat kecukupan kalsium yang normal $(\mathrm{OR}=9.4 ; 95 \% \mathrm{Cl}: 1.54-57.70)$, maka dapat disimpulkan tingkat kecukupan kalsium kurang merupakan faktor risiko atau penyebab terjadinya osteoporosis. Hal ini sesuai dengan Varenna et al. (2007) yang menyatakan bahwa tingkat kecukupan kalsium memiliki hubungan yang signifikan dengan kejadian osteoporosis. Wanita menopause yang kurang konsumsi kalsium berisiko untuk terkena osteoporosis (Heaney 2003).

Berdasarkan hasil analisis, tingkat kecukupan fosfor normal dapat berpeluang menjadi faktor risiko terhadap kejadian osteoporosis dibandingkan dengan tingkat kecukupan fosfor kurang. Hasil ini sesuai dengan studi pustaka yang menyebutkan bahwa jumlah fosfor yang lebih besar daripada kalsium akan menyebabkan berkurangnya massa tulang, karena kelebihan fosfor dapat meningkatkan sekresi hormon paratiroid. Hormon paratiroid merupakan hormon yang mencegah terjadinya hipokalsemia dalam darah dengan cara meningkatkan pengambilan kalsium pada tulang sehingga dapat menyebabkan kepadatan mineral tulang menjadi berkurang (Nakamura et al. 2005).

\section{Hubungan Status Gizi dan Aktivitas Fisik dengan Kejadian Osteoporosis}

Berdasarkan hasil analisis antara subjek yang memiliki status gizi lebih dengan status gizi normal menunjukkan bahwa status gizi normal cenderung berpeluang menjadi faktor risiko terhadap kejadian osteoporosis dibandingkan status gizi lebih. Individu dengan berat badan lebih tinggi cenderung untuk mempunyai kepadatan tulang lebih tinggi dibandingkan individu yang berat badannya rendah. Hal ini diduga karena cadangan lemak berfungsi sebagai bahan baku hormon androgen untuk diubah menjadi hormon estrogen. Oleh karena itu, individu terutama wanita yang gemuk jarang mengalami osteoporosis (Lane 2003).

Subjek yang memiliki tingkat aktivitas fisik dalam kategori kurang berpeluang mengalami os- 
teoporosis 8 kali lebih tinggi dibandingkan dengan subjek yang memiliki tingkat aktivitas fisik yang sedang (OR=8.7; 95\% Cl: 1.39-54.00), maka tingkat aktivitas fisik yang kurang merupakan faktor risiko atau penyebab terjadinya osteoporosis. Hal ini memperkuat hasil penelitian Sizer dan Whitney (2006) yang menunjukkan bahwa individu dengan aktivitas fisik yang baik memiliki efek positif terhadap kepadatan mineral tulang lebih tinggi dibandingkan individu yang hanya melakukan aktivitas fisik ringan.

\section{Faktor-faktor yang Memengaruhi Kejadian Osteo- porosis}

Uji multiregresi logistik menunjukkan bahwa tingkat kecukupan kalsium memiliki pengaruh yang lebih tinggi terhadap kejadian osteoporosis $(\mathrm{OR}=8.4$; 95\% Cl: 1.20-58.90) dibandingkan dengan tingkat aktivitas fisik pada subjek penelitian ini (OR=7.4; 95\% Cl: 0.98-58.70). Studi epidemiologis yang telah banyak dilakukan menunjukkan bahwa konsumsi kalsium memiliki keterkaitan yang cukup konsisten dengan kesehatan tulang (Kerstetter et al. 2003). Selain itu, individu yang jarang melakukan aktivitas fisik akan berpeluang mengalami patah tulang 2 kali lebih besar daripada yang sering melakukan aktivitas fisik (Lane 2003).

\section{KESIMPULAN}

Hasil penelitian menunjukkan bahwa tidak terdapat hubungan yang signifikan antara karakteristik subjek, tingkat kecukupan energi, protein, fosfor, dan status gizi dengan kejadian osteoporosis ( $p>0.05)$. Namun terdapat hubungan yang signifikan antara tingkat kecukupan kalsium dan aktivitas fisik dengan kejadian osteoporosis $(p<0.05)$. Uji multiregresi logistik menunjukkan bahwa tingkat kecukupan kalsium memiliki pengaruh lebih tinggi terhadap kejadian osteoporosis dibandingkan dengan aktivitas fisik. Tingkat kecukupan kalsium dan aktivitas fisik yang kurang merupakan faktor risiko terhadap kejadian osteoporosis pada subjek penelitian ini.

\section{DAFTAR PUSTAKA}

Beasley JM, Ichikawa LE, Ange BA, Spangler L, LaCroix AZ, Ott SM, \& Scholes D. 2010. Is protein intake associated with bone mineral density in young women? Am J Clin Nutr 2010, 91, 1311 $-1316$.

Broto R. 2004. Manifestasi klinis dan penatalaksanaan osteoporosis. Dexa Media, 2(17), 47-57.

Dawson-Hughes B. 1996. Calcium insufficiency and fracture risk. Osteoporosis International Journal, 3, 37-41.

Gur A, Nas K, Cevik R, Sarac AJ, Ataoglu S, Karakoc M. 2003. Influence of number of pregnancies on bone mineral density in postmenopausal women of different age groups. J Bone Miner Metab, 21, 234-41.

Harvey N \& Cooper C. 2004. Pencegahan Penyakit Osteoporosis dan Fraktur Panggul, dalam Buku Gizi Kesehatan Masyarakat (Public Health Nutrition). EGC, Jakarta.

Heaney RP. 2003. Long latency deficiency disease: Insights from calcium and vitamin D. Am J Clin Nutr, 78, 912-919.

Hitz. 2007. Bone mineral density and bone markers in patients with a recent low-energy fracture: effect of $1 \mathrm{y}$ of treatment with calcium and vitamin D. Am J Clin Nutr, 86, 251-259.

Hoger \& Hoeger. 2005. Lifetime Physical Fitness and Wellness, a Personalized Prog. Edisi ke-5. Thomson Wadsworth, USA.

Hsu YH, Venners SA, Terwedow HA, Feng Y, Niu T, Li Z, Laird N, Brain JD, Cummings SR, \& Bouxsein ML et al. 2006. Relation of body compotition, fat mass, serum lipids to osteoporosis fractures and bone mineral density in Chinese men and women. Am J Clin Nutr, 83, 146154.

Kerstetter JE, O’Brien KO, \& Insogna KL. 2003. Low protein intake: the impact on calcium and bone homeostatis in human. J Nutr, 133, 855-861.

Lane NE. 2003. Lebih Lengkap tentang Osteoporosis Edisi ke-2. PT Raja Grafindo Persada, Jakarta.

McCabe LD, Martin BR, McCabe GP, Johnston CC, Weaver CM, \& Peacock M. 2004. Dairy intakes affect bone density in the elderly. Am J Clin Nutr, 80(4), 1066-1074.

Nakamura K, Ueno K, \& Nishiwaki T. 2005. Nutrition, mild hyperparathyroidism and bone mineral density in young Japanese women. Am J Clin Nutr, 82, 1127-1133.

Rapuri PB, Gallagher JC, \& Haynatzka V. 2003. Protein intake: Effect on bone mineral density and the rate of bone loss in elderly women. Am J Clin Nutr, 77(6), 1517-1525.

Setyorini et al. 2009. Pencegahan osteoporosis dengan suplementasi kalsium dan vitamin D pada pengunaan kortikosteroid jangka panjang. E-Jurnal Universitas Udayana, 11(I), 32-8.

Sizer F \& Whitney EN. 2006. Nutrition Concept and Controversies 10th Edition. Thomson Adwords, USA.

Varenna M, Binelli L, Casari S, Zucchi, \& Sinigaglia L. 2007. Effect of dietary calcium intake on body weight and prevalence of osteoporosis in early postmenopausal women. Am J Clin Nutr 86, 639-644. 